\title{
Comparative Study of Azerbaijan and North-American Native Tribes' Folk Beliefs
}

\author{
Dosent Murshudova Ulduz Bashir ${ }^{1,2}$ \\ ${ }^{1}$ Department of Languages, Shaki Branch of Azerbaijan State Pedagogical University, Shaki, Azerbaijan \\ ${ }^{2}$ Department of Folklore and Ethnography, Azerbaijan National Academy of Sciences, Shaki, Azerbaijan
}

Email address:

ulduzshirin@gmail.com

\section{To cite this article:}

Dosent Murshudova Ulduz Bashir. Comparative Study of Azerbaijan and North-American Native Tribes' Folk Beliefs. International Journal of Architecture, Arts and Applications. Vol. 3, No. 4, 2017, pp. 63-67. doi: 10.11648/j.ijaaa.20170304.13

Received: June 27, 2017; Accepted: July 18, 2017; Published: July 27, 2017

\begin{abstract}
The comparative typology of Azerbaijan and North American natives' folk beliefs has been investigated in this research work. The beliefs dealing with names of months' of the year that are important in both Azerbaijan and North American Hindu cultures were studied. The Azerbaijan and North American natives have their own unique believes. That is certainly true for the sophisticated Azerbaijan and North American civilizations that developed in the different geographical area and climate of the world. Azerbaijan is situated in Eurasian continent and North American natives in North America continent, but some parallel beliefs have been found out after investigating comparatively.
\end{abstract}

Keywords: Collective Folk Mind, Month Belief, Comparison, Season Spirits

\section{Introduction}

Folk-belief is a broad genre of folklore and includes a wide variety of behaviors, expressions, and beliefs in folkloristic. The experience-based proof is the root of any kind of belief. Examples of concepts included in this genre are magic, superstition, popular belief, folk religion, planting signs, hoodoo, conjuration, charms, root work, taboos, old wives' tales, omens, portents, the supernatural and folk medicine. [1]

Folk-beliefs reflect the people's feelings and attitudes toward the world, community and things around them.

The Azerbaijan and North American Hindu tribes' emerged differently in many ways, they didn't encounter one another often because of large distance. But they share some of the same believes of the same themes.

Azerbaijan habitant and North American Native Tribes beliefs are cultural materials of the nation and transmitted orally from one generation to another. The messages are verbally transmitted in speech or song and in the form of folktales, sayings, proverbs, legends, songs, rituals or chants.

Both Azerbaijan and North American Native Tribes' beliefs serve as mirrors in which group of people can rule their life witnessing all the world wonders around them. Some stories reflect people's particular way of understanding tribes' believes.

Azerbaijan habitant and North American native tribes' beliefs find their way into the collective 'folk mind' in various ways and are the reflection of the reality of folk experiences and an attemption to understand them.

The cycling of the seasons was celebrated with ceremonies and rituals in Azerbaijan and North American Hindu tribes' traditional cultures. These ceremonies and rituals are a way of obtaining and maintaining harmony with the nature, living humans within health, happiness. People live close to the nature, show respect and warm greetings to the changing of new seasons around them. Because people don't want to take a risk of trouble and suffer, hunger and illness.

Azerbaijan and North American Hindu tribes recognized that the nature is imbued with spiritual significance. The spirits are regarded as ancestors of people and have all rights in the world. The power of spirits is controlled by mystical endless energy.

Both countries' native peoples believe that the Great Spirit-God created the human, the Earth and the sky. The gods and goddesses are of the most beautiful males and females and human was made in the image of god. Some folk religious say that God lives within us; some say God is on the seventh floor of the sky and keeps us under control. The forefathers' religious say that these gods play with our life, 
test, make the people happy or sad, solve our problems, make our life hard or easy, gift or punish us. The tribes' gods was described as human, animal, bird, plant shaped and people killed young and beautiful girls as a sacrifice for them.

For example, most Azerbaijan and North American natives' cultures were very interested in keeping track of time, so they developed complicated calendars which they used to predict important events, such as the changing of the seasons and eclipses of the sun or moon. They believed that they needed to know when these events would happen so they could make offerings and sacrifices to the gods, the forces of good and evil who controlled their lives.

The great civilizations that emerged from the early Azerbaijan and North American native cultures shared many other characteristics as well.

North American natives' religious practices included human sacrifice, which they believed was necessary to provide the blood and human hearts that nourished the gods. Azerbaijan ancient religious rituals sometimes included young and beautiful girls who were sacrificed as a symbolic gift to the god.

One of the ways we know how they lived and thought is through the hieroglyphics they carved in stone or rocks called codices, which were made of fig bark paper or deerskin that was folded like screens.

Both the Azerbaijanis and North American native tribes developed complex systems of government, constructed great cities that included temples and monuments used sophisticated agricultural methods, and held large markets at which all kinds of food and goods were sold. Their societies included different classes, or groups of people. The people at the top, such as the nobility, had the greatest wealth, while most ordinary people, such as peasants and laborers, were very poor. Both societies also included warriors, priests, skilled artisans, merchants, architects, astrologers, and artists. There were also professional dancers, singers, and musicians, who often participated in the many religious celebrations.

\section{Research Method}

It is natural that most of American native's folklore concepts, theories, and research methods are investigated and gained a big experience by the folklorists of USA. Folklore is defined as: "the traditional art, literature, knowledge, and practice that is disseminated largely through oral communication and behavioral example" in America. [2]

Folklore study of Azerbaijan is not in initial stage, but has successfully developed after gaining independence in Azerbaijan. Folklore is "Collective oral creativity, and the history of the culture of people" in Azerbaijan. [6]

The aim of this study is to research Azerbaijan and the North American natives' folk beliefs concerning the seasons and months of the year in Azerbaijan and North American culture within comparative method that are important in both Azerbaijan and North American native cultures.

The development of comparative study of Azerbaijan and the North American natives' folklore is still in the initial stage in Azerbaijan. Comparing the similarities and differences of folk beliefs from diverse cultural backgrounds is very challenging. Comparing Azerbaijan folk beliefs with North American native's folk beliefs is difficult because of the cultural values and the way of life, activities and thoughts.

After studying the both peoples beliefs concerning the seasons and months of the year, is identified some similarities between them.

Table 1. The similarities between Azerbaijan and the North American natives' folk beliefs.

\begin{tabular}{l}
\hline Azerbaijan beliefs about the months of the year are: \\
\hline Beliefs are one of the dominant form of folklore \\
Four seasons and twelve months are managed by powerful women \\
Each month has got a spirit and people fear them \\
Some spirits are tyrannical and some are benevolent \\
\hline
\end{tabular}

\subsection{Mythical Images of Goddesses of Winter Season}

Azerbaijan mythical image of goddess Chillee woman manages winter season. She is ugly with angry and dim eyes, her lower lip sweeps the ground and upper lip sweeps the sky. Her tangled hair is dirty. The meaning of Chillee is trouble and she brings suffering, disaster, hunger and cold for people. She does not love humans, and has got three grandsons: Great Chillee, Small Chillee, Chillee-Sprout-they are monthly spirits of December, January, February.

Flint is the winter spirit in The North American native folklore and one of the twin grandsons of goddess Sky Woman. Flint is a trickster figure, killed his mother. Flint is associated with winter, night, and death in many tribes. [2]

Chillee Woman and Flint are the negative and resented spirits and people were afraid of their destroying power and harming doings. Both Chillee Woman and Flint brought
North American beliefs about the months of the year are:

Each month has got a spirit and people fear them

Some spirits are ruthless and some are well disposed

Beliefs are one of the dominant form of folklore

Each month has got a spirit and people fear them

punishment to Azerbaijan and North American natives. So the people waited impatiently for the end of winter.

Great Chillee is December month's spirit in Azerbaijan culture and Chillee Woman sends him to the Mother Earth and says: Gather the people around the fire. Don't let them go out!"The native people don't stare at Full moon in this month because they believe that the moon can take them out to the death world.

Full Cold Moon or Full Long Nights Moon is December's spirit in North American native culture. During this month the winter becomes the coldest and nights are the longest and darkest. The term Long Night Moon is an undoubtedly appropriate name because the midwinter night is indeed long, and because the Moon is above the horizon for a long time. The midwinter full Moon has a high trajectory across the sky because it is opposite a low Sun. [3]

Both Great Chillee and Full Cold Moon are negative 
spirits and coldest month of a year and bring a lot of destruction and problems to the people.

Small Chillee is January spirit in Azerbaijan culture. The native people believes that the second grandson is the most brutal because it has been the face of the most severe month of the year. When Chillee Woman sends Small Chillee to the Mother Earth she says: "Take cold, hunger, illness to the people."

Full Wolf Moon is the January spirit in The North American native culture. This month is cold and there is deep snow in midwinter, the wolf packs howl hungrily outside of Indian villages. Sometimes it was called as the Old Moon. [3]

Both Small Chillee and Full Wolf Moon are dreadful, undesirable spirits and people prayed to stay alive and safe. The pitiless spirit kill plants and freeze the soil around their living places bring hunger to people and animals.

The third grandson Chillee Sprout is February's spirit in the culture of Azerbaijan. The mission of Chillee Sprout is to clear the nature from the feeble and sick living-beings and animals. Chillee Woman gives him the task: "Go and raze the people's fireplace and oven to the ground."

The Wednesday of the last week of February is ill-starred day and the people make some rituals for being safe and sound.

Native tribes of the north most often called February Full Snow Moon, because the heaviest snow usually falls during this month. Some tribes also referred to this Moon as the Full Hunger Moon, since harsh weather conditions in their areas made hunting very difficult.

Chillee Sprout and Full Hunger Moon are the most dangerous and devastating spirit in a year. No food, no hunting, no planting, no fruit gathering is available thus tribes are frightened of staving, freezing, dying.

\subsection{The Spirit of Spring Season}

Bahar Giz (Spring Girl) is beautiful, sharp minded and kind lady manages three months of the season in Azerbaijan culture.

Gray Month is March in Azerbaijan culture and people make ceremony and rituals for greeting Bahar Giz. [5] All the people look happy because of the greengrass are full for feeding the cattle, weather becomes warmer and nature wake up from the winter calamity. But the natives believe that this month can be angry and show its cruel face. That's why they are carefull and try not to fail this test. Some area is called this month as NatureCleaner because of all weak and ill living-beings are cleansed in this month.

March is Full Warm Moon in North American native's culture. As the temperature begins to warm and the ground begins to thaw, earthworm casts appear, heralding the return of the robins. The more northern tribes knew this Moon as the Full Crow Moon, when the cawing of crows signaled the end of winter; or the Full Crust Moon, because the snow cover becomes crusted from thawing by day and freezing at night. The Full Sap Moon, marking the time of tapping maple trees, is another variation. To the settlers, it was also known as the Lenten Moon, and was considered to be the last full

\section{Moon of winter.}

Gray Month and Full Warm Moon are warmly welcomed month and people take a deep breath of being alive, thanked and prayed to the gods for getting new and productive world.

April name is Spring Rains in Azerbaijan folk culture. It is called Rebirth month, too. This month depends on rain giving life to the soil. Spring rains is desired rain, because of rebirthing soil and plants.

Full Pink Moon-April is in North American native's culture. This name came from the herb moss pink, or wild ground phlox, which is one of the earliest widespread flowers of the spring. Other names for this month's celestial body include the Full Sprouting Grass Moon, The Egg Moon, and the Full Fish Moon, because this was the time that fish swam upstream to spawn.

Spring Rains and Full Pink Moon are months of celebration of the earth and nature. Everywhere is green and colorful, plants reborn again and birds build nests and animals reproduce more actively. People are busy with planting, hunting and gathering roots of plants.

May is Flower Month, Month of Beauty in some Azerbaijan regional folklore and Empty Month in others. The people don't marry, buy dwellings or move to a new house because they believe that you can't build successfully on a new foundation.

May is Full Flower Moon in Native American culture of the north; flowers are abundant everywhere during this time. Other names include the Full Corn Planting Moon, or the Milk Moon.

Flower Month and Full Flower Moon are the most beautiful month of a year and people are busy with horticulture.

\subsection{The Spirit of Summer Season}

Summer is the third season of the year and Warmblooded mother spirit rules the month in Azerbaijan culture and Nonoma in North American natives'.

Nonoma as a giant bird like the Thunderbird, is a powerful and well-respected spirit and associated with summer and the southern region. She is kindhearted. [4]

Mulberry-Bakhmaz Month, or Vaynana spirit manages the June in Azerbaijan folklore. Mulberry is known as paradise fruit and gives harvest in June. People cook juice of mulberry and prepare bakhmaz which is the most wholesome food.

Full Strawberry Moon is June spirit and this is a universal name to every tribe. However, because the relatively short season for harvesting strawberries comes each year during the month of June. So the full Moon that occurs during that month was christened for the strawberry!

Mulberry-Bakhmaz Month and Full Strawberry Moon are the friend of people and give crop and product to the people. While preparing the food people pray the god.

Gorabishiren spirit is the July month in Azerbaijan folklore.[5] The wheather becomes very hot and grapes ripe. There has been already plenty of fruit in this month in Azerbaijan. It is Abundance Month too.

The Full Buck Moon is July spirit. July is normally the 
month when the new antlers of buck deer push out of their foreheads in coatings of velvety fur. It was also often called the Full Thunder Moon, for the reason that thunderstorms are most frequent during this time. Another name for this month is the Full Hay Moon in North American native folklore.

Gorabishiren and The Full Buck Moon spirits are profusion and there are a lot of different off-make product in this month. People need rain and pray for it.

Azerbaijan people knew August as Guyrugdonan and pray gods for good weather.

Full Sturgeon Moon spirit is August and tribes fishing sturgeon, a large fish of the Great Lakes and other major bodies of water, were most readily caught during this month. A few tribes knew it as the Full Red Moon because, as the Moon rises, it appears reddish through any sultry haze. It was also called the Green Corn Moon or Grain Moon.

Both Guyrugdonan and Full Sturgeon Moon are the plenty of crop months and both people celebrate Harvest festival. They pray and sacrificed their produce to Gods to please the gods.

\subsection{The Spirit of Autumn or Fall Season}

Autumn or Fall Season is the traditional harvest time for most. Azerbaijan and Golden Guz was the first name. Autumn is associated with the Corn Goddess in Azerbaijan and Native American tribes' folklore. Spiritually, autumn is considered a symbol of changes in many North American tribes. Some tribes hold special Autumn Dances as part of their tribal dance traditions, and autumn is a favorable time of year for weddings.

September is known as the Harvest Month in Azerbaijan folklore. People collecting wild fruits, honey, herb gathering and reserves for the winter months.

Corn Moon or Full Harvest Moon is the name of September in The North American natives' folklore. The September full moon is actually the Harvest Moon and at the peak of harvest, it was easy for farmers to work late into the night by the light of this Moon. (6)

Harvest Month and Full Harvest Moon is the month of hard work and getting food reserves for winter. Both cultures have the harvest festival in this month.

Wedding Month is October in Azerbaijan culture. People marry in this month and think that it is suitable time of the year to build a family.

Full Hunter's Moon or Full Harvest Moon is the name of October. Some tribes call it Blood Moon, or Sanguine Moon. The leaves are falling from trees, the deer are fattened, and it's time to begin storing up meat for the long winter ahead. Because the fields were traditionally reaped in October, hunters could easily find fox and other animals to get meat for winter and the feast day among many Native American tribes.

November is known White frost Month, [6], [8] or Hunting Month. or Bear Sleeping Month in Azerbaijcan folklore. People are not afraid of bears to go to the forest for wood and hunting.

Full Beaver Moon is the name of November in North American natives' folklore. This was the time to set beaver traps before the swamps froze, to ensure a supply of warm winter furs. Another interpretation suggests that the name Full Beaver Moon comes from the fact that the beavers are now actively preparing for winter. It is sometimes also referred to as the Frosty Moon.

White frost Month and Full Beaver Moon are the hunting and making reserves for winter in both cultures.

\section{Result}

In this paper, four seasons and twelve months selected folk belief samples of two cultural groups are presented and all of them are from both Azerbaijan and North American native culture. Each group contains one story from both cultures, and the grouping was based on the similarity of the beliefs in characters, plot, or values. Both the comparison of similarities and differences are presented. In addition, some of the Azerbaijan folk belief that represented its unique cultural symbols is stressed as well.

\section{Discussion}

Folklore is a national culture and its research is the only way to explore the community, roots of ethnics, culture of nations, their feelings and point of views.

Modern folklore researchers study the folklore of the peoples of the world comparatively; analyze them with their similarities and differences, the main idea and contents, political-social, social-historical and everyday life of ethnic groups.

After independence of Azerbaijan, the work on taking note of folklore samples has been greatly enhanced, and strengthened. The folklorists classified the samples of folklore for the investigation, although folklore studies have been published on foreign press pages, but US and European folklore experts' knowledge on the Azerbaijani folklore are limited. Although Azerbaijan has rich cultural and moral folklore heritage, their fundamental comparative research has not been undertaken.

Comparative research of Azerbaijani and North American natives' traditions and their connection with the world literature is important for the development of folklore science and research is actual. It is important to explore the ideas of people's folk beliefs, the content of the folk beliefs, the nature of the folk beliefs, the superstation, Mentality, comparative analysis of beliefs and study of the problem are carried out in this paper.

\section{Conclusion}

It is concluded that basically there are some similarities and differences in the months' folk belief samples and studied in Azerbaijan and Native Americans folklore.

Azerbaijan and Native Americans believe in Great Spirit that is the creator and ruler of the universe. The most important Gods of both countries which rule all the seasons and months are:

a The Sun: sometimes is kind to people, gives them crop 
and sunny days, but sometimes is angry, gives them drought and hunger

b The Moon: sometimes is a man, sometimes is a woman

c The Wind is a man and a friendly spirit of their tribe (Yel Baba in Azerbaijan, Cyclone in North American native folklore)

d The Rain: sometimes is kind to people, but sometimes becomes angry and takes their life with destroying streams.

e The Lightning: it is the symbol of rain, Lightning gives order and then it rains. sometimes is kind to people, but sometimes is angry and takes their herd and shelter

Both people of Azerbaijan and Native America prayed them for abundance and were afraid of their anger. Each month is depends on season spirit and has specific characteristic features. [12, 13], [7]

We can see some parallel lines of month believes in Azerbaijan and North American natives'

a People see things as the sacred symbols of nature;

b Mythological month stories were the tribes' sacred and holy life;

c Spirits of months rule the whole world and people life.

d Season spirits are powerful sisters and rule the months

e Month spirits are their grandsons.

f Both Azerbaijan and North American natives hold ceremonies of dances and prayers to communicate with the spirits of heaven and thank the gods. Both believe that the heaven spirits are also dancing.

We can see some different lines of month beliefs in Azerbaijan and North American natives too.

a Some spirits of months are birds and animals in North American natives

b The 4 seasons own many natural forces/powers which are connected to the 4 phases of the Moon, phases of the Sun, the cycle of life, the 4 stages of life.

\section{References}

[1] Green, Thomas A. (1997). Folklore: An Encyclopedia of Beliefs, Customs, Tales, Music, and Art. Vol. 1. ABC-CLIO. səh. 89.
[2] http://www.afsnet.org/?page=whatisfolklore

[3] http://www.native-languages.org/pomola.htm

[4] http://farmersalmanac.com/full-moon-names/

[5] http://www.native-languages.org/nonoma.htm

[6] Azərbaycan ədəbiyyatı tarixi. Altı cilddə. Bakı-Elm -2004. $760 \mathrm{~s}$.

[7] http://www.native-languages.org/legends-autumn.htm

[8] Ramil Oliyev. Azərbaycan şifahi xalq ədəbiyyatı. Bakı-2014, $350 \mathrm{~s}$.

[9] Şəki folkloru örnəkləri. 1-ci kitab. Bak1, Nurlan nəşriyyat1, Folklor institutu 2014, 414 səh.

[10] Vəliyev K. Elin yaddaşı dilin yaddaşı, Bakı: 1987.

[11] Seyidov M. Azərbaycan xalqının soykökünü düşünərkən. Bakı:Yazıçı,1989,496 s.

[12] Abdullayev B. Haqqın səsi. Bakı, Azərnəşr, 1989, -144 s.

[13] Azərbaycan folkloru antologiyası. Azərb. EA nəşriyyatı. İ kitab. Bak1 2015. s.268.

[14] Abbasova I. Azərbaycan folkloru XIX əsr erməni mənbəələrində. Bak1, Elm,1977.-155 s.

[15] Azərbaycan nağılları. 5 cilddə. I cild, Bakı, Çıraq, 2016, -352 s.

[16] Wehner, K. 2002. Sakaki: sacred tree of Shinto. Mildred E. Mathias Botanical Garden Newsletter, 5(2). Internet document: www.botgard.ucla.edu/html/

[17] Abram, Susan Marie. ' 'Souls in the treetops:' Cherokee War, Masculinity, and Community, 1760-1820" Diss. Auburn University, August 10, 2009.

[18] American Indian Myths and Legends.

[19] Larry J. Zimmerman. American Indians. The first nation's life, myth, and art. 